\title{
Pengaruh Sosialisasi Terhadap Kepatuhan Warga dalam Membayar Kewajiban Pajak Bumi dan Bangunan di Desa Solokan Jeruk Kabupaten Bandung
}

\author{
Rahmadianti ${ }^{1}$, Ahmad Saepudin ${ }^{2}$ \\ ${ }^{1,2}$ Program Studi Akuntansi \\ ${ }^{1}$ Sekolah Tinggi Ilmu Ekonomi STAN IM, Jl. Jakarta No.79 Bandung \\ ${ }^{2}$ Sekolah Tinggi Ilmu Ekonomi Dharma Negara, Jl. Babakan Sari 1 No.68 Bandung \\ Email : rahmadianti0681@gmail.com ${ }^{1}$, ahmadsaepudinahmad50@gmail.com²
}

\begin{abstract}
ABSTRAK
Penelitian ini dilakukan di Desa Solokan Jeruk Kabupaten Bandung dengan tujuan untuk mengetahui tingkat sosialisasi, kepatuhan dan besarnya pengaruh sosialisasi terhadap kepatuhan warga dalam membayar kewajiban pajak bumi dan bangunan. Metode penelitian yang digunakan adalah penelitian survey dengan pendekatan kuantitatif. Populasi dalam penelitian ini sebanyak 1.419 orang. Teknik pengambilan sampel yang digunakan dalam penelitian ini adalah probability sampling berupa simple random sampling. Dengan menggunakan rumus dari Slovin dan taraf kesalahan (e) sebesar $10 \%$, maka jumlah sampel yang diambil sebanyak 93 orang. Teknik analisis data yang digunakan adalah teknik analisis korelasi Product Moment dan analisis regresi sederhana. Berdasarkan pada hasil pengujian hipotesis, menunjukkan bahwa sosialisasi perpajakan memiliki pengaruh yang signifikan terhadap kepatuhan.
\end{abstract}

Kata Kunci : Sosialisasi, Kepatuhan, Pajak Bumi dan Bangunan

\section{ABSTRACT}

This research was conducted in Solokan Jeruk Village, Bandung Regency with the aim of knowing the level of socialization, compliance and the magnitude of the influence of socialization on residents' compliance in paying land and building tax obligations. The research method used is survey research with a quantitative approach. The population in this study were 1,419 residents. The sampling technique used in this study was probability sampling in the form of simple random sampling. By using the formula from Slovin and the level of error (e) of 10\%, the number of samples taken is 93 people. The data analysis technique used is the Product Moment correlation analysis technique and simple regression analysis. Based on the results of hypothesis testing, it shows that taxation socialization has a significant effect on compliance.

Keywords: Socialization, Compliance, Land and Building Tax

\section{PENDAHULUAN}

Pembangunan adalah suatu proses kegiatan yang dilakukan dalam rangka pengembangan atau mengadakan perubahan-perubahan kearah keadaan yang lebih baik. Pembangunan yang ingin dicapai bangsa Indonesia adalah mewujudkan masyarakat 
yang adil dan makmur yang merata baik materil maupun spiritual berdasarkan Pancasila dan Undang - Undang Dasar 1945. Untuk meningkatkan pembangunan tersebut maka dibutuhkan anggaran.. Upaya pemerintah dalam menyerap anggaran adalah melalui sektor pajak, meskipun tidak kalah pentingnya pemasukan dari berbagai sektor pendapatan yang lain. Pajak adalah kontribusi wajib kepada negara yang terutang oleh orang pribadi atau badan yang bersifat memaksa berdasarkan Undang Undang, dengan tidak mendapat timbal balik secara langsung dan digunakan untuk keperluan negara bagi sebesar-besarnya kemakmuran rakyat (Undang-Undang Nomor 16 Tahun 2009, n.d.).

Setiap masyarakat terutama para wajib pajak harus sadar betul tentang pentingnya membayar pajak, bahwa pajak yang dikeluarkan bukan semata - mata untuk kepentingan pemerintah dan untuk menguntungkan pemerintah tetapi lebih dari pada itu untuk mengutamakan kepentingan rakyat. Wajib Pajak adalah orang pribadi atau badan, meliputi pembayar pajak, pemotong pajak, dan pemungut pajak, yang mempunyai hak dan kewajiban perpajakan sesuai dengan ketentuan peraturan perundang-undangan perpajakan (Resmi, 2019). Dengan dikeluarkannya Undang - Undang Nomor 12 Tahun 1985 yang selanjutnya disempurnakan dengan Undang-Undang Nomor 12 tahun 1994 Tentang Pajak Bumi Dan Bangunan, pemerintah mengadakan pembaharuan sistem perpajakan yang memberikan kepercayaan kepada wajib pajak dalam melaksanakan kewajiban serta memenuhi haknya dibidang perpajakan sehingga mewujudkan perluasan dan peningkatan kesadaran kewajiban perpajakan serta meratakan pendapatan masyarakat. Pajak Bumi dan Bangunan adalah pajak yang bersifat kebendaan dan besarnya pajak terutang ditentukan oleh keadaan objek atau bumi, tanah dan atau bangunan. Keadaan subjek (siapa yang membayar) tidak ikut menentukan besar pajak (Suandy, 2016).

Masih banyak masyarakat yang kurang paham akan pentingnya membayar Pajak Bumi dan Bangunan. Salah satunya disebabkan kurangnya sosialisasi. Sosialisasi perpajakan adalah usaha yang dilakukan oleh Direktorat Jenderal Pajak dalam memberikan pemahaman, menyampaikan informasi dan membina masyarakat untuk dapat memahami mengenai pentingnya pajak bagi negara (Novia Dewi, 2020). Adanya sosialisasi perpajakan akan meningkatkan kesadaran wajib pajak untuk membayar pajak serta mematuhi peraturan perpajakan. Sosialisasi ini masyarakat menjadi mengerti dan 
paham tentang manfaat membayar pajak serta sanksi jika tidak membayar pajak (G. Tegoeh Boediono, Riana Sitawati, 2018). Sosialisasi perpajakan menjadi salah faktor yang yang tidak dapat dipisahkan dalam peningkatan kepatuhan wajib pajak. Kepatuhan Wajib Pajak adalah tindakan Wajib Pajak dalam memenuhi kewajiban perpajakannya (Pasca Rizki Dwi Ananda, Srikandi Kumadji, 2015).

Fenomena yang terjadi di Desa Solokan Jeruk adalah masih banyak terdapat masyarakat yang belum melunasi atau masih menunggak dan kurang paham akan pentingnya membayar Pajak Bumi dan Bangunan. Salah satunya disebabkan oleh kurangnya sosialisasi dari aparat pemerintah Desa, sehingga mereka tidak merespon akan kesadaran membayar pajak tersebut.

Berdasarkan pada latar belakang di atas, maka dirumuskan permasalahan sebagai berikut : (1) Bagaimana sosialisasi Pajak Bumi dan Bangunan ?, (2) Bagaimana kepatuhan warga dalam membayar kewajiban pajak ?, (3) Seberapa besar pengaruh sosialisasi terhadap kepatuhan warga dalam membayar kewajiban Pajak Bumi dan Bangunan di Desa Solokan Jeruk Kabupaten Bandung?.

\section{METODE PENELITIAN}

Penelitian ini menggunakan metode penelitian survey dengan pendekatan kuantitatif. Populasi dalam penelitian ini adalah warga yang berada di Desa Solokan Jeruk Kabupaten Bandung sebanyak 1.419 orang. Teknik pengambilan sampel yang digunakan dalam penelitian ini adalah probability sampling berupa simple random sampling. Dengan menggunakan rumus dari Slovin dan taraf kesalahan $(e)$ sebesar 10\%, maka jumlah sampel yang diambil sebanyak 93 orang.

Teknik pengumpulan data yang dilakukan melalui kuesioner, dokumentasi dan wawancara. Untuk mengetahui pendapat dari responden mengenai sosialisasi dan kepatuhan warga dalam membayar kewajiban pajak bumi dan bangunan dilakukan dengan menyebarkan kuesioner kepada responden, mengumpulkan kembali kuesioner yang telah disebarkan kepada responden, dan kemudian melakukan tabulasi hasil kuesioner dan memberi nilai sesuai dengan sistem nilai yang ditetapkan.

Uji kualitas data dilakukan dengan uji validitas dan uji reliabilitas. Teknik analisis data yang digunakan adalah teknik analisis korelasi Product Moment dan analisis 
regresi sederhana. Uji hipotesis dilakukan secara parsial. Berdasarkan perhitungan korelasi maka diperoleh koefisien determinasi.

\section{HASIL DAN PEMBAHASAN}

Berdasarkan perhitungan diperoleh bahwa tingkat persetujuan terhadap sosialisasi sebesar $80,38 \%$ dari total $100 \%$ yang diharapkan. Secara kontinum dapat digambarkan seperti berikut :

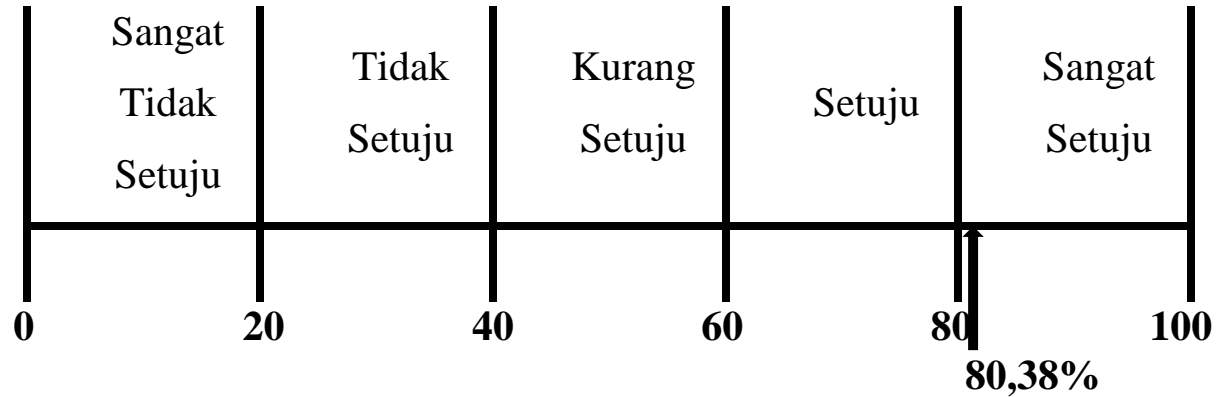

Gambar 1: Garis Kontinum Sosialisasi

Hal ini mengindikasikan bahwa warga Desa Solokan Jeruk sangat setuju dengan adanya sosialisasi perpajakan.

Berdasarkan perhitungan diperoleh bahwa tingkat persetujuan terhadap kepatuhan warga dalam membayar kewajiban pajak bumi dan bangunan sebesar 79,83\% dari total $100 \%$ yang diharapkan. Secara kontinum dapat digambarkan seperti berikut :

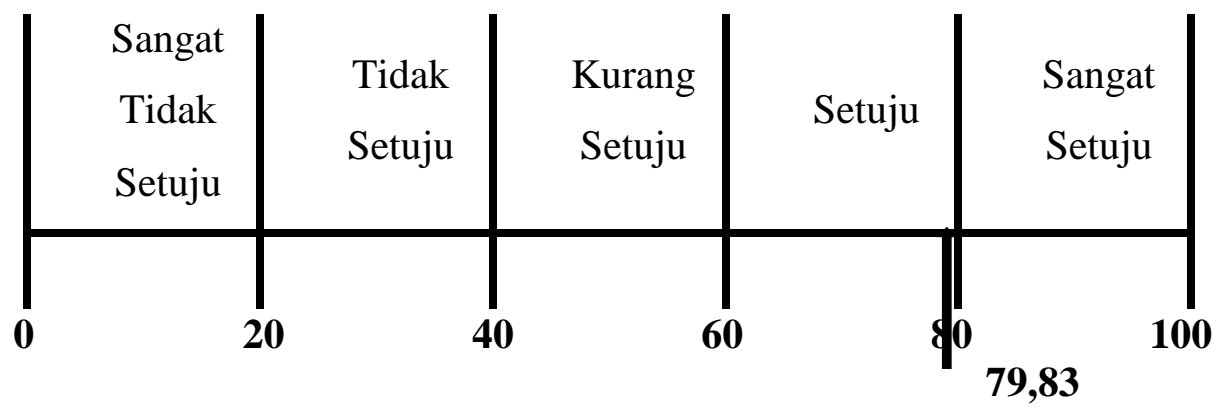

Gambar 2: Garis Kontinum Kepatuhan Warga

Hal ini mengindikasikan bahwa warga di Desa Solokan Jeruk setuju dalam kepatuhan membayar kewajiban pajak bumi dan bangunan. 
Hubungan antar variabel yang diteliti disajikan dalam tabel berikut :

Tabel 1. Correlations

Correlations

\begin{tabular}{llrr}
\hline & & \multicolumn{1}{c}{ Sosialisasi } & Kepatuhan \\
\hline \multirow{2}{*}{ Sosialisasi } & Pearson Correlation & 1 &, $728^{* *}$ \\
\cline { 2 - 4 } & Sig. (2-tailed) & 93 &, 000 \\
\cline { 2 - 4 } & $\mathrm{N}$ &, $728^{* *}$ & 93 \\
\hline \multirow{2}{*}{ Kepatuhan } & Pearson Correlation &, 000 & 1 \\
\cline { 2 - 4 } & Sig. (2-tailed) & 93 & 93 \\
\cline { 2 - 4 } & $\mathrm{N}$ & & \\
\hline${ }^{* *}$. Correlation is significant at the 0.01 level (2-tailed). & & \\
\end{tabular}

Sumber : SPSS versi 22

Sesuai dengan tabel diatas terlihat hubungan antar variabel memenuhi kategori signifikan pada level $1 \%$ dan 5\%, dengan demikian semua variabel bisa diolah lebih lanjut.

Hasil analisis regresi linear sederhana dengan menggunakan program SPSS Statistics Subscription, diperoleh hasil perhitungan sebagai berikut :

Tabel 2. Hasil Analisis Regresi Linier Sederhana

\begin{tabular}{|c|c|c|c|c|c|c|}
\hline \multicolumn{7}{|c|}{ Coefficients $^{\mathrm{a}}$} \\
\hline & \multirow[b]{3}{*}{ Model } & \multirow{2}{*}{\multicolumn{2}{|c|}{$\begin{array}{l}\text { Unstandardized } \\
\text { Coefficients }\end{array}$}} & \multirow{3}{*}{$\begin{array}{l}\text { Standardized } \\
\text { Coefficients } \\
\text { Beta }\end{array}$} & \multirow[b]{3}{*}{$\mathrm{t}$} & \multirow[b]{3}{*}{ Sig. } \\
\hline & & & & & & \\
\hline & & B & Std. Error & & & \\
\hline \multirow[t]{2}{*}{1} & (Constant) & 9,170 & 3,860 & & 2,376 &, 020 \\
\hline & Sosialisasi & ,952 & ,094 & ,728 & 10,135 & ,000 \\
\hline
\end{tabular}

a. Dependent Variable: Kepatuhan

Sumber : SPSS versi 22

Berdasarkan Tabel 2 diatas maka diperoleh persamaan regresi sebagai berikut :

$$
Y=9,170+0,952 X
$$

Hasil analisis regresi linier sederhana diperoleh nilai a sebesar 9,170 sedangkan nilai b sebesar 0,952. Dari persamaan di atas menunjukkan bahwa nilai $a$ dan $b$ positif. 
Artinya ketika variabel X (sosialisasi) dinaikkan maka nilai Y (kepatuhan) akan naik mengikuti perubahan variabel $\mathrm{X}$.

Berdasarkan Tabel 2 dan uji hipotesis secara parsial yang telah dilakukan diperoleh nilai $t_{\text {hitung }}$ sebesar 10,135 sedangkan $t_{\text {tabel }}$ dengan $\alpha=0,05$ diperoleh nilai sebesar 2,000. Hasil tersebut menunjukkan bahwa $t_{\text {hitung }}$ lebih besar dari $t_{\text {tabel }}(10,135>$ 2,000), sehingga hipotesis dapat diterima. Hasil dari perhitungan tersebut menunjukkan bahwa sosialisasi berpengaruh signifikan terhadap kepatuhan warga dalam membayar kewajiban pajak bumi dan bangunan di Desa Solokan Jeruk Kabupaten Bandung.

Koefisien determinasi yang diperoleh sebagai berikut :

Tabel 3. Model Summary

\begin{tabular}{llrrr}
\hline Model & R & $\begin{array}{r}\text { R } \\
\text { Square }\end{array}$ & $\begin{array}{c}\text { Adjusted R } \\
\text { Square }\end{array}$ & $\begin{array}{l}\text { Std. Error of } \\
\text { the Estimate }\end{array}$ \\
\hline 1 &, $728^{\mathrm{a}}$ &, 530 &, 525 & 3,148 \\
\hline
\end{tabular}

a.Predictors: (Constant), Sosialisasi

Sumber : SPSS versi 22

Besarnya kontribusi pengaruh sosialisasi terhadap kepatuhan warga dalam membayar kewajiban pajak bumi dan bangunan sebesar 53\%, sedangkan sisanya $47 \%$ dipengaruhi oleh faktor lain yang tidak diteliti dalam penelitian ini. Faktor - faktor tersebut antara lain tingkat pendidikan, tingkat pendapatan, dan alasan - alasan lain yang mungkin ada dan belum terungkap.

\section{SIMPULAN}

Berdasarkan data yang diperoleh bahwa warga Desa Solokan Jeruk Kabupaten Bandung sangat setuju dengan adanya sosialisasi perpajakan. Warga Desa Solokan Jeruk Kabupaten Bandung setuju dalam kepatuhan membayar kewajiban Pajak Bumi dan Bangunan. Antara sosialisasi dengan kepatuhan terdapat pengaruh yang positif, ini menunjukkan bahwa sosialisasi memiliki pengaruh yang signifikan terhadap kepatuhan warga dalam membayar kewajiban pajak bumi dan bangunan di Desa Solokan Jeruk Kabupaten Bandung. Oleh sebab itu petugas pajak bumi dan bangunan diharapkan dapat memberikan informasi lebih lanjut kepada warga mengenai kelas tanah, letak tanah, peruntukan dan pemanfaatan tanah / bangunan sehingga mereka dapat memahami dan 
mengerti hak dan kewajibannya serta setiap setahun sekali perlu diadakan pendataan wajib pajak baru tentang kepemilikan tanah dan bangunan agar dapat diketahui data tentang obyek pajak yang terbaru di Desa Solokan Jeruk Kabupaten Bandung.

\section{DAFTAR PUSTAKA}

G. Tegoeh Boediono, Riana Sitawati, S. H. (2018). Analisis Pengaruh Sosialisasi Perpajakan Terhadap Kepatuhan Wajib Pajak Dengan Kesadaran Sebagai Variabel Mediasi. Jurnal Penelitian Ekonomi Dan Bisnis, 3(1)(Maret), 22-38. http://www.jpeb.dinus.ac.id

Novia Dewi, M. A. P. (2020). Pengaruh Sosialisasi Perpajakan Dan Sanksi Perpajakan Terhadap Kepatuhan Wajib Pajak Orang Pribadi. Scientia Journal, Jurnal Ilmiah Mahasiswa, $\quad 1 \quad$ No.2(Oktober), 1-10. http://ejournal.upbatam.ac.id/index.php/scientia_journal/article/view/2527

Pasca Rizki Dwi Ananda, Srikandi Kumadji, A. H. (2015). Pengaruh Sosialisasi Perpajakan, Tarif Pajak Dan Pemahaman Perpajakan Terhadap Kepatuhan Wajib Pajak (Studi Pada UMKM Yang Terdaftar Sebagai Wajib Pajak Di Kantor Pelayanan Pajak Pratama Batu). Jurnal Mahasiswa Perpajakan (Jejak), 6 No.2, 1-9. http://perpajakan.studentjournal.ub.ac.id/

Resmi, S. (2019). Perpajakan, Teori dan Kasus (11th ed.). Jakarta : Salemba Empat.

Suandy, E. (2016). Hukum Pajak (7th ed.). Jakarta : Salemba Empat.

Undang-Undang Nomor 16 Tahun 2009. (n.d.). https://www.pajak.go.id/ 